\title{
The Role of Tourism in Economic Growth: Empirical Evidence from Saudi Arabia
}

\author{
Sana Naseem (D)
}

Citation: Naseem, Sana. 2021. The Role of Tourism in Economic Growth: Empirical Evidence from Saudi Arabia. Economies 9: 117. https:// doi.org/10.3390/economies9030117

Academic Editors: Ralf Fendel and Andreia Dionísio

Received: 16 June 2021

Accepted: 13 August 2021

Published: 18 August 2021

Publisher's Note: MDPI stays neutral with regard to jurisdictional claims in published maps and institutional affiliations.

Copyright: (C) 2021 by the author. Licensee MDPI, Basel, Switzerland. This article is an open access article distributed under the terms and conditions of the Creative Commons Attribution (CC BY) license (https:// creativecommons.org/licenses/by/ $4.0 /)$.
Department of Accounting and Finance, College of Business Administration (COBA), Al Yamamah University, 7010 King Fahd Road, Al Qirawan, Riyadh 13541, Saudi Arabia; s_naseem@yu.edu.sa

\begin{abstract}
Tourism is vital to the success of many economies worldwide and has been a widely researched area for many years. Unfortunately, an insufficient number of studies have been conducted on this subject in the context of Saudi Arabia. Therefore, this research investigates the role of tourism in promoting economic growth in the Kingdom of Saudi Arabia by using annual time series data from 2003 to 2019. The study uses basic statistics, correlation coefficients, the unit root test, the Johansen co-integration test, the co-integration regression test and the Granger causality test to check the relationship between tourism and economic growth. The results show that economic growth has a long-run relationship with tourism receipts, tourism expenditures and the number of tourist arrivals; the number of tourist arrivals has a strong relationship with economic growth, compared to other parameters. The empirical results validate the concept that tourism promotes economic growth in the kingdom of Saudi Arabia.
\end{abstract}

Keywords: tourism; economic growth; Saudi Arabia

JEL Classification: C01; F41; F43; O53

\section{Introduction}

In the current context, tourism is an essential element in developing the world economy and is one of the leading sources of revenue for advanced and emerging countries (Costa 2017; Mason 2015). Given the study of Turner and Freiermuth (2016), tourism has become a strong pillar for sustainable development for both developed and emerging economies, as it offers various cultural, social, technological, experiential, and natural products for leisure and business. In this connection, the World Travel and Tourism Council (WTTC 2021) revealed that travel and tourism plays a vital role in the creation of jobs, both including its direct, indirect and induced impacts; it estimated that 1 in 4 jobs created across the world, i.e., about 334 million or $10.6 \%$ of all jobs, accounted for USD 9.2 trillion, 10.4\% of global GDP. Meanwhile, international visitor spending amounted to $6.8 \%$ of total exports and $27.4 \%$ of global services exports, contributing USD 1.7 trillion in 2019 . Thus, tourism is considered a significant part of the trade-in international services and has become a prominent and growing industry.

Tourism participates in a country's growth and development, primarily by bringing in multiple economic values and benefits, and secondly, by helping to build brand value, image, and identification in the region. As a significant contributor to economic growth, the tourism industry goes beyond attractive destinations (Khalil et al. 2007). It plays a considerable role in boosting the economy of a nation. For most of the country, tourism is supposed to be the main engine for regional development, accelerating recent economic activity. It has a positive impact on revenue growth, job opportunities, gross income, and production, but it can hurt the environment, due to such factors as road congestion, pollution, and ecosystem destruction (Ren et al. 2019). By drawing international tourists, tourism contributes to generating foreign exchange earnings that generate employment, improved infrastructure, and quality of life, contributing to the country's sustainable 
economic growth, as tourists add to the area's sales, profits, salaries, tax revenue, and exports (FaladeObalade and Dubey 2014). The most direct effects are for industries such as hotels, restaurants, transportation, entertainment, and shopping. A literature review suggests that tourism, agriculture, capital, and energy development support growth in most developing nations. The development of tourism has gained global acknowledgement as a motivation for economic growth, agriculture, energy development and alleviating poverty. Tourism development is widely believed to lead to economic growth, although scholars disagree over the empirical research (Khan et al. 2020).

A booming tourism sector can generate the same growth in income such as that from exports of natural resources. Unlike the oil, gas, and mineral extraction industries that trigger natural resource degradation, the tourism sector can become a green sector (Tuncay and Ozcan 2020). In Saudi Arabia, the contribution of GDP and total employment generated by travel and tourism accounted for $9.5 \%$ and $11.2 \%$ (WTTC 2019); hence it is a viable option to move ahead toward sustainable tourism with less reliance on traditional means of raising economic growth.

The Kingdom of Saudi Arabia is one of the world's leading economies in terms of tourism. Tourism is crucial to the growth of many economies around the world and has been a subject of extensive research for many years, but very few studies have been conducted in the context of this country. So, this research investigates the role of tourism in promoting economic growth in the Kingdom of Saudi Arabia. The core objective of the study is to examine the role of tourism receipts, tourism expenditure, and number of tourist arrivals on the economic growth of Kingdom of Saudi Arabia and to explore the relationship among these. This study used annual data from 2003 to 2019 and employed basic statistics, correlation coefficients, a unit root test, a Johansen co-integration test, a co-integration regression test and a Granger causality test for the empirical investigation. Given that this study contributes to the body of knowledge on the role of tourism in the economic growth of Saudi Arabia, it also adds a significant value to policy and practice. Precisely, the empirical findings confirmed that the tourism promote economic growth in the kingdom of Saudi Arabia. To the best of the researcher's knowledge, this is the first paper in the literature to investigate the relationship between economic growth and the number of tourist arrivals in the context of Saudi Arabia, and this is the paper's main novelty.

To achieve the main objective, the researcher built a graphical framework for the current study, as depicted in Figure 1. The remaining part of the study is organized as follows. Section 2 reviews past studies depicted in the literature review section. Section 3 presents the data and methodology. Section 4 describes the results based on the econometric analysis. Section 5 includes the discussion. Lastly, Section 6 includes the conclusion, limitations, and some future studies. 


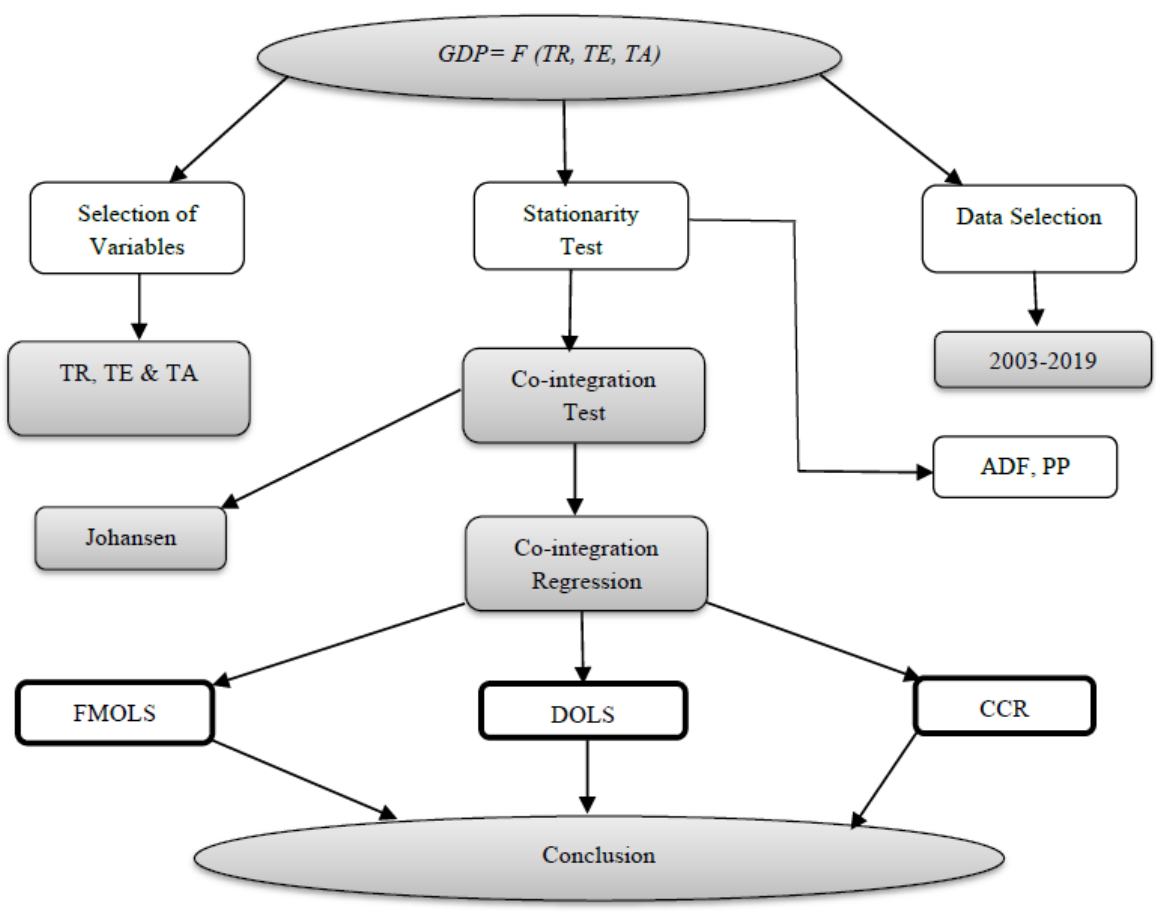

Figure 1. Research Framework.

\section{Literature Review}

A plethora of literature reveals the long-term influence of tourism on economic growth, known as the tourism-led growth hypothesis. It can act as a growth engine by contributing to GDP growth, job creation, and foreign exchange generation (Alhowaish 2016). In contrast, economic growth also positively impacts tourism development, as it favors tourism activities by developing facilities and infrastructures, such as transportation development, information and communication technology development, electronic money, hotels, restaurants, and other entertainment services and facilities.

Despite using several research methodologies based on time series and panel data analytical techniques, experimental studies have shown mixed or even inconsistent results supporting the tourism-led economic growth hypothesis. In this regard, numerous studies that investigated the association between tourism and economic growth by using the Granger causality test on time-series data analysis include those of Gunduz and Hatemi-J (2005); Brida et al. (2008); Chen and Chiou-Wei (2009); Belloumi (2010); Akinboade and Braimoh (2010); Tang and Abosedra (2012); Tang and Tan (2013); Manzoor et al. (2019); and Songling et al. (2019). These studies are in support of the tourism-led growth hypothesis.

Moreover, studies such as those of Dritsakis (2004); Kim et al. (2006); and Lee and Chien (2008) established the validity of the feedback hypothesis, while those of Oh (2005); Ozturk and Acaravci (2009); Tang and Jang (2009); and Payne and Mervar (2010) presented evidence of no association between the two variables. Nevertheless, other empirical studies examined the relationship between tourism development and economic growth using cross-section or panel data. Among these studies, those of Leitão (2015); Tavares and Leitao (2017); Leitão and Shahbaz (2016); Lee and Chang (2008); Po and Huang (2008); Proenca and Soukiazis (2008); Falk (2010); Holzner (2011); Ekanayake and Long (2012); Lee and Brahmasrene (2013); Aslan (2014); Chou (2013); Surugiu et al. (2011); and Tugcu (2014) obtained mixed results for the relationship between tourism and economic growth. Additionally, these results are sensitive to the specific group of countries under examination.

Oh (2005) found that the Korean economy needs a long-term balance between tourism growth and economic expansion. The outcomes of the Granger causality test suggest that economic-driven tourism growth has a one-way causal relation. So, the Korean economy 
does not bear the prospect of tourism-led economic growth. Khalil et al. (2007) found that the affiliation among tourism receipts and economic expansion is good and concluded that economic expansion is necessary to develop tourism in Pakistan. Akan et al. (2008) investigated the causal affiliations among Turkey's tourism and economic expansion by using the Granger causality test, Phillips-Perron test, the co-integration approach, and a Vector Auto Regression (VAR) model for the period 1985-2007. They revealed that tourism had a strong effect on economic expansion. They further indicated that there is a long-term steady correlation between tourism growth and economic development.

Nissan et al. (2011) tried to determine whether tourism activity can stimulate economic progression. They also indicated the main parameters that affected tourism activity and showed a feedback effect on income and tourism. Additionally, they identified that tourism supplies necessary funds to finance firms' activities, stimulates the local firms' productivity and creates new job opportunities that increase the country's welfare. Kreishan (2011) used the Autoregressive Distributed Lag (ARDL) model from 1990 to 2014 to empirically investigate the tourism-led growth hypothesis (TLGH). He found that there was a strong bond amid tourism expansion and economic progress in Bahrain. Furthermore, his outcomes revealed that there was a one-way Granger causality flowing from tourism to economic growth. He concludes that tourism had a positive effect on the Bahrain economy and suggested that, if the Bahrain government strategically strengthened its tourism sector, it may have a substantial opportunity to enhance its economic progression.

Adnan and Khan (2013) confirmed the long-run relationship between tourism receipt and economic growth; they further explained that tourism receipt led to an increase in Pakistan's economic growth, except for 2006-2008. Wang and Ma (2015) found a significant and robust correlation between the GDP in Guihoz of China and the tourist income. Bayramoglu and Ari (2015) found substantial one-way causation running from the expenditures of foreign tourists who visited Greece to Greece's economic growth, at a $1 \%$ level of significance. Tang and Tan (2015) found that tourism has a substantial impact on the Malaysian economic growth both in the long run and short run; the Granger causality test indicated that tourism Granger-causes economic growth. Ahad (2016) advocated the tourism-led growth for Pakistan, as two-way causation exists among tourism expenditure and economic growth. Ohlan (2017) also found long-run one-way causation running from tourism to economic growth. Tabash (2017) revealed the same in that there is a unique longterm relationship between tourism receipts and economic growth. He further proposed that the Palestinian government develop dynamic policies to promote tourism, which leads to generating employment opportunities, poverty alleviation, and economic growth.

Lee and Syah (2018) conducted a study in Indonesia to examine the mass impact of tourism on the regional tourism destination from the economic and environmental perspective throughout 1980-2015. The research used co-integration regression analysis using Fully Modified OLS (FMOLS), Dynamic OLS (DOLS) and Canonical co-integration regression. The results depict a long-run equilibrium relationship between tourism receipts, environmental degradation, and economic growth, while in the short-run, tourism growth and agriculture land growth were positively associated. They concluded that tourism growth will have a positive impact on the economy, but at the exact moment, it will lead to environmental degradation. Hence, tourism growth will have an inverse relationship with the environment.

Mustafa (2019) conducted a study on Sri Lanka to evaluate FDI and the tourism receipts' role throughout 1978-2016. The Kernel Fit and Confidence Ellipse graph showed a strong positive association between the variable GDP and FDI. The same finding was retrieved by co-integration and Granger causality, suggesting a two-way causality between tourism receipts and GDP.

Badulescu et al. (2020) investigated the relationship between Gross Domestic Product (GDP) per capita and international tourism in Romania over the 1995-2016 period by using the Johansen cointegration test and Granger causality. Their results confirmed the growthled tourism hypothesis (GLTH) in the long run (with respect to both international tourism 
receipt, and international tourism arrivals). In the short run, the tourism-led growth hypothesis (TLGH) was supported for the relationship between GDP and international tourism receipt, and a bidirectional causal relationship between GDP and the number of international tourist arrivals. Jamel (2020) conducted a study on Saudi Arabia to examine the causal nexus between tourism and economic growth. The research used descriptive analysis, a Pearson correlation test, a unit root test, a VAR model and a Granger causality test for the period 1990 to 2018. The empirical results revealed that the economic growth in Saudi Arabia was positively affected by tourism and there is a positive nexus among tourism and economic growth. Further, a bidirectional nexus was found between tourism and economic growth in Saudi Arabia.

Jeon (2020) initiated a study in Korea to investigate the association between macro and non-macro variables on tourism companies' stock performance. The study included monthly data from January 2001 to December 2018. The results revealed that variables such as oil prices, exchange rate, and industrial production have an adverse effect on tourism companies' stock prices, while the effects of tourism expenditure and consumer price index are positive and significant. The quantile regression also revealed the negative effect of non-macro determinants on tourism stock. He concluded that macro and non-macro variables are statistically asymmetric and highly correlated to tourism stock performance.

Khan (2020) tried to explore the role of tourism in boosting Italy's economic growth, where she stated that there is a robust causal effect among such variables as economic growth, number of tourist arrival, international tourism receipt, and international tourism expenditure. Further, she revealed bidirectional causation between economic growth and tourism growth and economic growth to tourist arrivals. However, she also found unidirectional causality between economic growth to tourism expenditure, tourism growth to tourism expenditure, and more interestingly, she found no causal association between tourist arrivals and tourism expenditure.

Therefore, from the previous studies, it is observed that there is lot of literature on the tourism growth nexus. Studies on tourism's effects on economic growth have been few in Gulf Cooperation Council (GCC) countries, particularly in Saudi Arabia. As a result, the researcher aimed to investigate the relationship between tourism and economic growth in Saudi Arabia. Hence, this research is based on the following hypotheses:

Hypothesis 1 (H1). There is a long-run relationship among the tourism receipts, tourism expenditure, number of tourist arrivals, and economic growth.

Hypothesis 2 (H2). Economic growth has a stronger relationship with the number of tourist arrivals in Saudi Arabia than other exogenous variables.

\section{Data and Methodology}

Due to data unavailability in the data bank of The World Bank, yearly time series from 2003 to 2019-17 observations - are considered in our study, which should be sufficient to capture the short-run as well as long-run correlations between tourism growth (measured in terms of tourism receipt TR), tourism expenditure (TE) (measured in terms of tourism expenditure), and number of tourist arrivals (TA) and economic growth (measured in terms of GDP) in this model. All data sets are taken from World Development Indicators in current USD.

The data used in the model of the study were first tested by the descriptive statistics, followed by the correlation coefficient test and the stationarity test to be evaluated based on the Augmented Dicky-Fuller test (ADF) by Dickey and Fuller $(1979,1981)$ and by Phillips-Perron (PP) unit root test by Phillips and Perron (1988) as an essential tool to evaluate the relevant information for the model. Later, a co-integration test conducted by Engle and Granger (1987) transcribed that if two or more variables in time-series are co-integrated, there is always an equal error correction representation in which a deviation from equilibrium influences the short-run dynamics of the variables in the system. Thus, the co-integrated variables must have an error correction representation in the model, 
representing an error correction term. That is why a vector error correction model is formulated to revive the information lost in the differencing process, thereby allowing for long-run equilibrium and short-run dynamics. The vector error correction model implies changes in one (variable) function of the level of disequilibrium in the co-integrating relationship (i.e., captured by the error correction term) and changes in other explanatory variables. Numerous estimation methods for testing a single co-integrating vector and an error correction term are available; among them, Fully Modified Ordinary Least Squares (FMOLS) by Phillips and Hansen (1990), Canonical Co-integrating Regression (CCR) by Park (1992), and Dynamic Ordinary Least Square (DOLS) by Saikkonen (1992) and Stock and Watson (1993) are used in this study. The Hansen Instability co-integration test is assessed to predict the co-integration regression viability test. Lastly, the causal linkage between the selected variables is investigated by the Granger causality test.

The model followed in the study, taken from Khan (2020) and applied to evaluate the role of tourism in the context of the Kingdom of Saudi Arabia, can be formulated as follows:

Economic growth $=f$ (tourism growth, tourism expenditure, tourist arrivals)

All the parameters are used in a real term and converted into a logarithmic function:

$$
L Y t=\log (Y t) .
$$

This can also be constituted in a log-linear econometric structure as follows:

$\log (\mathrm{GDP}) t=\beta 0+\beta 1 \log$ (tourism receipts) $t+\beta 2 \log$ (tourism expenditure) $t+\beta 3 \log$ (number of tourist arrival) $t+\varepsilon t$

where $\beta 0$ is the constant term, $\beta 1$ is the coefficient of a variable (tourism receipts), $\beta 2$ is the coefficient of variables (tourism expenditure), $\beta 3$ is the coefficient of variables (number of tourist arrivals), $t$ is the time trend, and $\varepsilon t$ presumes the random error term to be normally, uniformly, and autonomously distributed.

The long-run model can be expressed as follows:

$$
L N G_{t}=a_{0}+a_{1} L N T R_{t}+a_{2} L N T E_{t}+a_{3} L N T A_{t}+\varepsilon_{t}
$$

In the short run, our model can be expressed as follows:

$$
L N G_{t}=a+\sum_{i}^{k}=1 \beta_{i} L N G_{t-i}+\sum_{j}^{k}=1 \varnothing_{j} L N T R_{t-j}+\sum_{m}^{k}=1 \partial_{m} L N T E_{t-m}+\sum_{n}^{k}=1 \theta_{n} L N T A_{t-n}+u_{1 t}
$$

where LNG represents the log value of economic growth, LNTR represents the log tourism receipts, LNTE represents the log value of tourism expenditure, LNTA represents the log value of number of tourist arrivals, a is the coefficient, and $u$ represents the error.

\section{Results}

\subsection{Descriptive Statistics}

Descriptive statistics indicating the mean, median, maximum, and minimum values of the selected parameters with the Jarque-Bera and probability values and the correlation matrix of the selected parameters' log form, as shown in Table 1. The correlation matrix indicates a strong positive correlation among the variables. That means that the endogenous variable, i.e., economic growth, and exogenous variable, i.e., tourism receipts, are strongly correlated with the coefficient of 0.834 . Therefore, an increase of 1 percent in tourism receipts leads to an increase of 0.834 percent in economic growth. Similarly, an increase of 1 percent in tourism expenditure leads to an increase of 0.82 percent in economic growth, and a 1 percent increase in the number of tourist arrivals leads to an increase of 0.925 percent in economic growth. 
Table 1. Descriptive statistics with a correlation matrix.

\begin{tabular}{ccccccccccc}
\hline $\begin{array}{c}\text { Dependent } \\
\text { Variable }\end{array}$ & Mean & Median & Maximum & Minimum & Jarque-Bera & Probability & LNG & LNTR & LNTE & LNTA \\
\hline LNG & 26.99 & 27.192 & 27.399 & 26.098 & 2.185 & 0.335 & 1 & & \\
\hline LNTR & 22.86 & 22.852 & 27.711 & 21.952 & 0.23 & 0.891 & 0.834 & 1 & \\
\hline LNTE & 23.44 & 23.613 & 23.948 & 22.149 & 9.736 & 0.008 & 0.817 & 0.562 & 1 \\
\hline LNTA & 16.56 & 16.682 & 16.951 & 15.808 & 1.589 & 0.452 & 0.925 & 0.804 & 0.746 \\
\hline
\end{tabular}

\subsection{Unit Root Test}

The data are analyzed for the augmented Dickey-Fuller stationarity test and PhillipsPerron test, as depicted in Table 2. The series become stationary at the level for the tourism expenditure, while for tourism receipts and the number of tourist arrivals, the time-series become stationary at the first difference level at the intercept level, and the autoregressive vector lag is one.

Table 2. Unit root test.

\begin{tabular}{cccccc}
\hline Dependent & & \multicolumn{2}{c}{ ADF. } & \multicolumn{2}{c}{ Phillips-Perron } \\
\hline Variable & & $t$-Statistic & Prob. & Adj. $t$-Stat. & Prob. \\
\hline \multirow{2}{*}{ LNG } & Level & -2.637 & 0.106 & -4.705 & $0.002^{*}$ \\
& 1st difference & -3.428 & $0.027^{* *}$ & & \\
\hline \multirow{2}{*}{ LNTR } & Level & 0.907 & 0.99 & -0.778 & 0.798 \\
& 1st difference & -7.65 & $0.00^{*}$ & -9.005 & $0.000^{*}$ \\
\hline \multirow{2}{*}{ LNTE } & Level & -3.171 & $0.041^{* *}$ & -4.158 & $0.006^{*}$ \\
\hline \multirow{2}{*}{ LNTA } & Level & -2.615 & 0.11 & -3.15 & $0.042^{* *}$ \\
& 1st difference & -4.499 & $0.004^{*}$ & & \\
\hline
\end{tabular}

*** represents 1 and $5 \%$ significance level. Source: author's computation.

\subsection{Johansen Co-Integration Test}

After testing the stationarity test, our task is to check the co-integration test for the variables. To perform co-integration, the Johansen test for co-integration is used, and the conditional model with four variables can be specified as follows:

$$
H_{0}: b_{1 i}=b_{2 i}=b_{3 i}=b_{4 i}=0 H_{A}: b_{1 i} \neq b_{2 i} \neq b_{3 i} \neq b_{4 i} \neq 0
$$

where $i=1,2$, and 3 .

The acceptance of $H_{0}$ indicates the short-run relationship and for the short-run VAR model to be investigated further, while accepting $H_{A}$ indicates the long-run relationship and for the Error Correction Model to be investigated.

Table 3 reveals the presence of co-integration indicating the long-run relationship among the variables at the 0.05 significance level. The long-run equation can be expressed as follows:

$$
L N G_{t}=-0.994 L N T R_{t}-1.41 L N T E_{t}-0.265 L N T A_{t}
$$

According to the long-run equation, a 1 percent increase in the tourism receipts will cause a rise of 99.4 percent in the GDP, while a 1 percent increase in tourism expenditure leads to an increase of 141 percent in the GDP. On the other hand, a 1 percent increase in the number of tourist arrivals will increase by 26.5 percent the GDP. 
Table 3. Johansen co-integration test for LNG as a dependent variable.

\begin{tabular}{cccccccc}
\hline & Eigenvalue & $\begin{array}{c}\text { Trace } \\
\text { Statistics }\end{array}$ & $\begin{array}{c}\mathbf{0 . 0 5} \text { Critical } \\
\text { Value }\end{array}$ & Prob. ${ }^{* *}$ & $\begin{array}{c}\text { Max-Eigen } \\
\text { Statistics }\end{array}$ & $\begin{array}{c}\text { 0.05 Critical } \\
\text { Value }\end{array}$ & Prob. ${ }^{* *}$ \\
\hline None $^{*}$ & 0.897 & 65.578 & 47.856 & 0.0005 & 34.07 & 27.584 & 0.0064 \\
\hline At most $1{ }^{*}$ & 0.813 & 31.507 & 29.797 & 0.0315 & 25.143 & 21.132 & 0.0129 \\
\hline At most 2 & 0.301 & 6.364 & 15.495 & 0.6525 & 5.364 & 14.265 & 0.6953 \\
\hline At most 3 & 0.065 & 0.999 & 3.841 & 0.3174 & 0.999 & 3.842 & 0.3174 \\
\hline \multicolumn{2}{c}{ LNGDP } & & & & LNTE & & LNTA \\
\hline 1 & & -0.994 & $(0.44)$ & -1.41 & $(0.191)$ & -0.265 & $(0.793)$ \\
\hline
\end{tabular}

* denotes rejection of the hypothesis at the 0.05 level, ${ }^{* *}$ MacKinnon et al. (1999) $p$-values.

\subsection{Co-Integration Regression}

Table 4 delineates the co-integration regression by FMOLS, DOLS, and CCR for tourism receipts, tourism expenditure, and the number of tourist arrivals on economic growth considering the dependent variable. The FMOLS results suggest that all the parameters are related to economic growth, while the DOLS suggests that only the tourism receipts and tourist arrivals affect economic growth. The CCR also indicates that all the parameters are related to economic growth. The co-integration model is tested by the Hansen instability co-integration test and the Jarque-Bera test and is found to be significant.

Table 4. Co-integration regression.

\begin{tabular}{lcccccc}
\hline \multicolumn{1}{c}{ Variable } & \multicolumn{2}{c}{ FMOLS } & \multicolumn{2}{c}{ DOLS } & \multicolumn{2}{c}{ CCR } \\
\hline LNTR & 0.28 & $0.0209^{* *}$ & 0.312 & $0.05^{* *}$ & 0.317 & $0.032^{* *}$ \\
\hline LNTE & 0.256 & $0.015^{* *}$ & 0.287 & 0.23 & 0.235 & $0.0286^{* *}$ \\
\hline LNTA & 0.62 & $0.008^{*}$ & 0.989 & $0.04^{* *}$ & 0.574 & $0.024^{* *}$ \\
\hline C & 4.34 & 0.059 & 10.54 & 0.139 & 4.753 & $0.009^{*}$ \\
\hline Adj R & \multicolumn{2}{c}{0.86} & \multicolumn{2}{c}{0.997} & \multicolumn{2}{c}{0.853} \\
\hline Long-run Variance & \multicolumn{2}{c}{0.014} & \multicolumn{2}{c}{$6.78 \times 10^{-5}$} & \multicolumn{2}{c}{0.014} \\
\hline Co-integration test & 0.29 & 0.200 & 0.069 & 0.200 & 0.244 & 0.200 \\
\hline Jarque-Bera & 1.346 & 0.51 & 0.467 & 0.792 & 1.301 & 0.522 \\
\hline
\end{tabular}

C: co-integration coefficient deterministic; ${ }^{*},{ }^{* *}$ represents 1 and 5 percent significance.

The co-integration analysis showed the long-term relationship between tourism activity and economic growth in Saudi Arabia.

\subsection{Granger Causality Test}

Furthermore, this study conducted a Granger causality test with a lag length of 1 to confirm the causal relationship between the variables. The results of the Granger causality are shown in Table 5.

The results indicate that the variables are significant at a $5 \%$ level, and there is a causal relation between LNTA and LNG. Thus, it states that LNG affects LNTA in Saudi Arabia, supporting the tourism-led growth hypothesis; the direction is unidirectional causality between economic growth and tourist arrivals. 
Table 5. Granger causality test.

\begin{tabular}{cccc}
\hline Null Hypothesis & Obs. & F-Statistics & Probability \\
\hline LNTA does not Granger cause LNG & \multirow{2}{*}{16} & 2.90152 & 0.1123 \\
LNG does not Granger cause LNTA & & 9.34552 & 0.0092 \\
\hline LNTE does not Granger cause LNG & \multirow{2}{*}{16} & 0.85377 & 0.3723 \\
LNG does not Granger cause LNTE & & 0.13732 & 0.7169 \\
\hline LNTR does not Granger cause LNG & \multirow{2}{*}{16} & 1.92603 & 0.1885 \\
LNG does not Granger cause LNTR & & 0.25776 & 0.6202 \\
\hline LNTE does not Granger cause LNTA & \multirow{2}{*}{16} & 1.97735 & 0.1831 \\
LNTA does not Granger cause LNTE & & 0.58823 & 0.4568 \\
\hline LNTR does not Granger cause LNTA & \multirow{2}{*}{16} & 0.41381 & 0.5312 \\
LNTA does not Granger cause LNTR & & 0.14988 & 0.7049 \\
\hline LNTR does not Granger cause LNTE & \multirow{2}{*}{16} & 0.04247 & 0.8399 \\
LNTE does not Granger cause LNTR & & 0.19091 & 0.6693 \\
\hline
\end{tabular}

\section{Discussion}

Economic growth has a strong relationship with tourism receipts, tourism expenditures, and the number of tourist arrivals, as the correlation analysis suggests that all the variables have a positive correlation of more than 80 percent. The studied data were tested for unit root test and found to be significant at the zero and first-order difference; later, they were tested for the Johansen co-integration test, which revealed the presence of both short- and long-run relationships among the endogenous and exogenous variables. Thus, they showed a long-run relationship among the variables, leading to the acceptance of Hypothesis 1.

After the co-integration test, the co-integration regression test was executed for FMOLS, DOLS and CCR. The findings of FMOLS revealed that all the exogenous variables have a strong relationship with the endogenous variables; among the exogenous variables, the number of tourist arrivals have the highest coefficient value of 0.62 , significant at the 1 percent level, 0.28 for the tourism receipts and 0.256 for tourism expenditure, both significant at the 5 percent level. The DOLS revealed the number of tourist arrivals to be 0.989 and 0.32 for tourism receipts, both significant at the 5 percent level, but the tourism expenditure is not significant. While the CCR reveals that the number of tourist arrivals has a coefficient value of $0.574,0.317$ for the tourism receipts and 0.235 for the tourism expenditures, all are significant at 5 percent. The Hensen instability, Jarque-Bera and adjusted R-square are significant, and thus, the model is stable and viable. Hence, Hypothesis 2 proves to be viable for the number of tourist arrivals.

The Granger causality test revealed that economic growth leads to the number of tourist arrivals of Saudi Arabia, as the same findings were retrieved from other relevant studies that investigated the association between economic growth and tourism by using the Granger causality test on time-series data analysis, including those of Balaguer and Cantavella-Jorda (2002); Durbarry (2004); Gunduz and Hatemi-J (2005); Brida et al. (2008); Chen and Chiou-Wei (2009); Belloumi (2010); Akinboade and Braimoh (2010); Tang and Abosedra (2012); and Tang and Tan (2013).

\section{Conclusions}

This study is an effort to explore the tourism sector's role in determining the economic growth in the Kingdom of Saudi Arabia. The stationarity test showed that tourism receipts, tourism expenditure, number of tourist arrivals, and economic growth become stationary at zero, and the first-order difference. The Johansen co-integration test revealed a long-run relationship among the parameters where economic growth is endogenous and others are exogenous variables. The FMOLS finding revealed that all the exogenous variables have a significant relationship, but the DOLS model revealed that two are significant out of three exogenous variables. Simultaneously, the CCR depicted all the exogenous variables having 
a significant relationship with the endogenous variable. All three co-integration models are significant and stable as predicted by the Hansen instability test and Jarque-Bera normality test. The study results are significant for policymakers for tourism in Saudi Arabia. This study presents strong empirical findings about the long-run and short-run relationships between tourism and economic growth. It is proposed that policymakers should give considerable attention to the promotion of sustainable tourism to boost economic growth in Saudi Arabia. Moreover, policymakers should pay significant attention to domestic and international tourism in Saudi Arabia, improve the infrastructure of various tourist attractions and streamline the visa application procedure for international visitors.

This study has some limitations. These limitations may necessitate future studies. Firstly, the current study was conducted in the context of Saudi Arabia; future research studies should be conducted in other developing countries to ensure that the findings are generalizable. Secondly, the current study relied on secondary data. Hence, future research may concentrate on primary data to investigate the effect of the tourism industry on economic growth. Lastly, this study used relatively short-length annual time series data, so future research can use long length data with more advanced techniques and variables.

Funding: This research was funded by Al Yamamah University, Riyadh, Saudi Arabia.

Institutional Review Board Statement: Not Applicable.

Informed Consent Statement: Not Applicable.

Data Availability Statement: Data used in this paper is available from the World Bank. https: // data.worldbank.org/country/SA (accessed on 27 February 2020).

Conflicts of Interest: The authors declare no conflict of interest.

\section{References}

Adnan, Hye Qazi Muhammad, and Rana Ejaz Ali Khan. 2013. Tourism-led growth hypothesis: A case study of Pakistan. Asia Pacific Journal of Tourism Research 18: 303-13. [CrossRef]

Ahad, Muhammad. 2016. Does Tourism-led Growth Hypothesis exist in Pakistan? A fresh look from Combine Co-integration and Causality Approach with Structural Breaks. International Journal of Economics and Empirical Research 4: 94-111.

Akan, Yusuf, İbrahim Arslan, and Cem Isik. 2008. The Impact of Tourism on Economic Growth: The Case of Turkey. Journal of Tourism 9: 47-69.

Akinboade, Oludele A., and Lydia A. Braimoh. 2010. International tourism and economic development in South Africa: A Granger causality test. International Journal of Tourism Research 12: 149-63. [CrossRef]

Alhowaish, Abdulkarim K. 2016. Is Tourism Development a Sustainable Economic Growth Strategy in the Long Run? Evidence from GCC Countries. Sustainability 8: 605. [CrossRef]

Aslan, Alper. 2014. Tourism development and economic growth in the Mediterranean countries: Evidence from panel Granger causality tests. Current Issues in Tourism 17: 363-72. [CrossRef]

Badulescu, Alina, Daniel Badulescu, Ramona Simut, and Simona Dzitac. 2020. Tourism-Economic growth nexus. The case of Romania. Technological and Economic Development of Economy 26: 867-84. [CrossRef]

Balaguer, Jacint, and Manuel Cantavella-Jorda. 2002. Tourism as a Long-Run Economic Growth Factor The Spanish Case. Applied Economics 34: 877-84. [CrossRef]

Bayramoglu, Turgut, and Yilmaz Onur Ari. 2015. The relationship between tourism and economic growth in Greece economy: A time series analysis. Computational Method in Social Sciences 3: 89-93.

Belloumi, Mounir. 2010. The relationship between tourism receipts, real effective exchange rate and economic growth in Tunisia. International Journal of Tourism Research 12: 550-60. [CrossRef]

Brida, Juan Gabriel, Edgar J. Sanchez Carrera, and W. Adrian Risso. 2008. Tourism's Impact on long-run Mexican economic growth. Economics Bulletin 3: 1-8.

Chen, Ching-Fu, and Song Zan Chiou-Wei. 2009. Tourism Expansion, Tourism Uncertainty and Economic Growth: New Evidence from Taiwan and Korea. Tourism Management 30: 39-44. [CrossRef]

Chou, Ming Che. 2013. Does Tourism Development Promote Economic Growth in Transition Countries? A Panel Data Analysis. Economic Modelling 33: 226-32.

Costa, Jorge. 2017. How are companies and destinations "surfing the wave" of global tourism? Strategic question overview. Worldwide Hospitality and Tourism Themes 9: 588-91. [CrossRef]

Dickey, David A., and Wayne A. Fuller. 1979. Distribution of the estimators for autoregressive time series with a unit root. Journal of the American Statistical Association 74: 427-31. 
Dickey, David A., and Wayne A. Fuller. 1981. Likelihood ratio statistics for autoregressive time series with a unit root. Econometrica 49: 1057-71. [CrossRef]

Dritsakis, Nikolaos. 2004. Tourism as a long-run economic growth factor: An empirical investigation for Greece using causality analysis. Tourism Economics 10: 305-16. [CrossRef]

Durbarry, Ramesh. 2004. Tourism and Economic Growth: The Case of Mauritius. Tourism Economics 10: 389-401. [CrossRef]

Ekanayake, Ekanayake M., and Aubrey E. Long. 2012. Tourism Development and Economic Growth in Developing Countries. International Journal of Bussiness and Finance Research 6: 51-63.

Engle, Robert F., and Clive W. J. Granger. 1987. Cointegration and error correction: Representation, estimation and testing. Econometrica 55: 251-76. [CrossRef]

FaladeObalade, Timothy A., and Suchi Dubey. 2014. Managing Tourism as a source of Revenue and Foreign direct investment inflow in a developing Country: The Jordanian Experience. International Journal of Academic Research in Economics and Management Sciences 3: 16-42. [CrossRef]

Falk, Martin. 2010. A dynamic panel data analysis of snow depth and winter tourism. Tourism Management 31: 912-24. [CrossRef]

Gunduz, Lokman, and Abdulnasser Hatemi-J. 2005. Is the tourism-led growth hypothesis valid for Turkey? Applied Economics 12: 499-504. [CrossRef]

Holzner, Mario. 2011. Tourism and economic growth: The beach disease? Tourism Management 32: 922-33. [CrossRef]

Jamel, Lamia. 2020. The Relation between Tourism and Economic Growth: A Case of Saudi Arabia as an Emerging Tourism Destination. Virtual Economics 3: 29-47. [CrossRef]

Jeon, Ji-Hong. 2020. Macro and Non-macro Determinants of Korean Tourism Stock Performance: A Quantile Regression Approach. Journal of Asian Finance, Economics and Business 7: 149-56. [CrossRef]

Khalil, Samina, Mehmood Khan Kakar, and Afia Malik. 2007. Role of tourism in Economic Growth: Empirical Evidence from Pakistan Economy. The Pakistan Development Review 46: 985-95. [CrossRef]

Khan, Uzma. 2020. Does Tourism Boost Economic Growth: An Evidence from Italy. International Journal of Economics and Business Administration 8: 214-22. [CrossRef]

Khan, Asif, Sughra Bibi, Ardito Lorenzo, Jiaying Lyu, and Zaheer Udden Babar. 2020. Tourism and Development in Developing Economies: A Policy Implication Perspective. Sustainability 12: 1618. [CrossRef]

Kim, Hyun Jeong, Ming-Hsiang Chen, and SooCheong Shawn Jang. 2006. Tourism expansion and economic development: The case of Taiwan. Tourism Management 27: 925-33. [CrossRef] [PubMed]

Kreishan, Fuad M. 2011. Empirical Study of Tourism and Economic Growth of Bahrain: An ARDL Bounds Testing Approach. International Journal of Economics and Finance 7: 1-9. [CrossRef]

Lee, Jung Wan, and Tantatape Brahmasrene. 2013. Investigating the influence of tourism on economic growth and carbon emissions: Evidence from panel analysis of the European Union. Tourism Management 38: 69-76. [CrossRef]

Lee, Chien-Chiang, and Chun-Ping Chang. 2008. Tourism development and economic growth: A closer look at panels. Tourism Management 29: 180-92. [CrossRef]

Lee, Chien-Chiang, and Mei-Se Chien. 2008. Structural breaks, tourism development, and economic growth: Evidence from Taiwan. Mathematics and Computers in Simulation 77: 358-68. [CrossRef]

Lee, Jung Wan, and Ahmad Mujafar Syah. 2018. Economic and Environmental Impacts of Mass Tourism on Regional Tourism Destinations in Indonesia. Journal of Asian Finance, Economics and Business 5: 31-41. [CrossRef]

Leitão, Nuno Carlos. 2015. Portuguese Tourism Demand: A Dynamic Panel Data Analysis. International Journal of Economics and Financial Issues 5: 673-77.

Leitão, Nuno Carlos, and Muhammad Shahbaz. 2016. Economic Growth, Tourism Arrivals and Climate Change. Bulletin of Energy Economics (BEE). Economics and Social Development Organization (TESDO) 4: 35-43.

MacKinnon, James G., Alfred A. Haug, and Leo Michelis. 1999. Numerical Distribution Functions of Likelihood Ratio Tests for Cointegration. Journal of Applied Econometrics 14: 563-77. [CrossRef]

Manzoor, Faiza, Longbao Wei, Muhammad Asif, Muhammad Zia ul Haq, and Hafiz ur Rehman. 2019. The Contribution of Sustainable Tourism toEconomic Growth and Employment in Pakistan. International Journal of Environmental Research and Public Health 16: 3785. [CrossRef] [PubMed]

Mason, Peter. 2015. Tourism Impacts, Planning and Management. Arbingdon: Routledge.

Mustafa, Abdul Majeed Mohamed. 2019. Contribution of Tourism and Foreign Direct Investment to Gross Domestic Product: Econometric Analysis in the Case of Sri Lanka. Journal of Asian Finance, Economics and Business 6: 109-14. [CrossRef]

Nissan, Edward, Miguel-Angel Galindo, and María Teresa Méndez. 2011. Relationship between tourism and economic growth. The Service Industries Journal 31: 1567-72. [CrossRef]

Oh, Chi-Ok. 2005. The contribution of tourism development to economic growth in the Korean economy. Tourism Management 26: 39-44. [CrossRef]

Ohlan, Ramphul. 2017. The relationship between tourism, financial development and economic growth in India. Future Business Journal 3: 9-22. [CrossRef]

Ozturk, Ilhan, and Ali Acaravci. 2009. On the causality between tourism growth and economic growth: Empirical evidence from Turkey. Transylvanian Review of Administrative Sciences 25: 73-81.

Park, Joon. 1992. Canonical Cointegrating Regressions. Econometrica 60: 119-43. [CrossRef] 
Payne, James E., and Andrea Mervar. 2010. The tourism-growth nexus in Croatia. Tourism Economics 19: 1089-94. [CrossRef]

Phillips, Peter C. B., and Bruce E. Hansen. 1990. Statistical inference in instrumental variable regression with I (1) processes. Review of Economic Studies 57: 99-125. [CrossRef]

Phillips, Peter C. B., and Pierre Perron. 1988. Testing for a unit root in time series regression. Biometrika 75: 335-46. [CrossRef]

Po, Wan-Chen, and Bwo-Nung Huang. 2008. Tourism development and economic growth-A nonlinear approach. Physica A: Statistical Mechanics and its Applications 387: 5535-42. [CrossRef]

Proenca, Sara, and Elias Soukiazis. 2008. Tourism as an economic growth factor: A case study for Southern European Countries. Tourism Economics 14: 791-806. [CrossRef]

Ren, Taizeng, Muhlis Can, Sudharshan R. Paramati, Jianchun Fang, and Wanshan Wu. 2019. The Impact of Tourism Quality on Economic Development and Environment: Evidence from Mediterranean Countries. Sustainability 11: 2296. [CrossRef]

Saikkonen, Pentti. 1992. Estimation and testing of co-integrated systems by an autoregressive approximation. Econometric Theory 8: 1-27. [CrossRef]

Songling, Yang, Muhammad Ishtiaq, and Bui Thi Thanh. 2019. Tourism Industry and Economic Growth Nexus in Beijing, China. Economies 7: 25. [CrossRef]

Stock, James H., and Mark W. Watson. 1993. A simple estimator of co-integrating vectors in higher order integrated systems. Econometrica 61: 783-820. [CrossRef]

Surugiu, Camelia, Nuno Carlos Leitão, and Marius Răzvan Surugiu. 2011. A Panel Data Modelling of International Tourism Demand: Evidences for Romania. Economic Research Ekonomska Istraživanja 24: 134-45. [CrossRef]

Tabash, Mosab I. 2017. The Role of Tourism Sector in Economic Growth: An Empirical Evidence from Palestine. International Journal of Economics and Financial Issues 7: 103-8.

Tang, Chor Foon, and Salah Abosedra. 2012. Small sample evidence on the tourism-led growth hypothesis in Lebanon. Current Issues in Tourism 17: 234-46. [CrossRef]

Tang, Chun-Hung Hugo, and SooCheong Shawn Jang. 2009. The tourism-economy causality in the United States: A sub-industry level examination. Tourism Management 30: 553-58. [CrossRef]

Tang, Chor Foon, and Eu Chye Tan. 2013. How stable is the tourism-led growth hypothesis in Malaysia? Evidence from disaggregated Tourism Markets. Tourism Management 37: 52-47. [CrossRef]

Tang, Chor Foon, and Eu Chye Tan. 2015. Does tourism effectively stimulate Malaysia's economic growth? Tourism Management 46: 158-63. [CrossRef]

Tavares, Jean Max, and Nuno Carlos Leitao. 2017. The Determinants of International Tourism Demands for Brazil. Tourism Economics 23: 834-45. [CrossRef]

Tugcu, Can Tansel. 2014. Tourism and Economic Growth Nexus Revisited: A Panel Causality Analysis for the case of the Mediterranean Region. Tourism Management 42: 207-12. [CrossRef]

Tuncay, Nesrin, and Ceyhun Can Ozcan. 2020. The effect of Dutch Disease in the tourism sector: The case of Mediterranean Countries. Tourism and Hospitality Management 26: 99-114. [CrossRef]

Turner, Rochelle, and Evelyne Freiermuth. 2016. Travel \& Tourism Economic Impact 2016. London: World Travel \& Tourism Council.

Wang, Wei, and Haiying Ma. 2015. On Econometric Analysis of the Relationship between GDP and Tourism Income in Guizhou, China. International Journal of Business Administration 6: 41-47. [CrossRef]

WTTC. 2019. WTTC Economic Impact Reports. Available online: https://wttc.org/Research/Economic-Impact (accessed on 20 June 2019).

WTTC. 2021. Global Economic Impact and Trends 2021. Available online: https://wttc.org/Portals/0/Documents / Reports/2021 /Global\%20Economic\%20Impact\%20and\%20Trends\%202021.pdf?ver=2021-07-01-114957-177 (accessed on 21 June 2021). 